\title{
Die leksikografiese aanbieding en behandeling van vaste uitdrukkings*
}

\author{
Rufus H. Gouws, Departement Afrikaans en Nederlands, \\ Universiteit Stellenbosch, Stellenbosch, Suid-Afrika \\ (rhg@sun.ac.za)
}

\begin{abstract}
Opsomming: Vir leksikograwe is dit belangrik om in hulle besluite oor die insluiting van vaste uitdrukkings in hulle woordeboeke vertroud te wees met die status van vaste uitdrukkings as volwaardige leksikale items. Hierdie status behoort 'n invloed te hê op die manier waarop vaste uitdrukkings aangebied en behandel word. Na aanleiding van die behandeling in bepaalde woordeboeke word daar in hierdie artikel aangevoer dat vaste uitdrukkings lemmastatus in woordeboeke moet kry en wel deur as sublemmata opgeneem te word in 'n geneste teksblok wat geheg word aan die artikel van 'n lemma wat 'n sleutelwoord uit die vaste uitdrukking verteenwoordig. Die behandeling moet van ' $n$ omvattender aard wees as wat tans die geval is in algemene woordeboeke. 'n Fokus op leksikografiese funksies vra om die insluiting van sekere aanduidertipes in die behandeling. Dit sluit onder meer etimologiese data in, asook eksplisiete leiding ten opsigte van kultuurgebonde vaste uitdrukkings.
\end{abstract}

Sleutelwoorde: AANDUIDER, DEELARTIKELTRAJEK, GIDSELEMENT, IDIOME, KOGNITIEWE FUNKSIE, KONTEKSLEIDING, KOTEKSLEIDING, KULTUURGEBONDE ITEMS, LEKSIKOGRAFIESE BEHANDELING, LEKSIKOGRAFIESE FUNKSIES, LEMMATEKEN, LEMMATIESE ADRESSERING, NES, NIELEMMATIESE ADRESSERING, NIS, SUBLEMMA, VASTE UITDRUKKINGS

\begin{abstract}
The Lexicographic Presentation and Treatment of Fixed Expressions. In their decisions regarding the inclusion of fixed expressions in their dictionaries it is important for lexicographers to be familiar with the status of fixed expressions as fully-fledged lexical items. This status should have an influence on the way in which fixed expressions are presented and treated. With reference to the treatment allocated to fixed expressions in a few dictionaries it is argued in this paper that they should be awarded lemma status in dictionaries. It is proposed that fixed expressions should be included as sublemmata, presented in a nested text block that is attached to the article of a lemma representing a keyword from the fixed expression. Their treatment should be more comprehensive than what is currently found in prevailing general dictionaries. A focus on lexicographic functions demands the inclusion of certain item types in the treatment of fixed expressions. This includes etymological data as well as much more explicit guidance with regard to culture-bound lexical items.
\end{abstract}

* $\quad$ Hierdie artikel is 'n verwerking van ' $n$ referaat gelewer by die internasionale kongres "EUROPHRAS 2012 Maribor: Phraseology and Culture", aangebied deur die European Society of Phraseology, by die Universiteit Maribor, Maribor, Slowenië, 27-31 Augustus 2012. 
Keywords: COGNITIVE FUNCTION, CONTEXTUAL GUIDANCE, COTEXTUAL GUIDANCE, CULTURE-BOUND ITEMS, FIXED EXPRESSION, GUIDING ELEMENT, IDIOMS, ITEM, LEMMA SIGN, LEMMATIC ADDRESSING, LEXICOGRAPHIC FUNCTIONS, LEXICOGRAPHIC TREATMENT, NEST, NICHE, NONLEMMATIC ADDRESSING, PARTIAL ARTICLE STRETCH, SUBLEMMA

\section{Inleiding}

Vaste uitdrukkings word in 'n verskeidenheid woordeboektipes opgeneem, aangebied en behandel, onder meer in woordeboeke met vaste uitdrukkings as enigste teiken van leksikografiese behandeling asook algemene eentalige en tweetalige woordeboeke gerig op 'n weergawe en behandeling van items uit die algemene leksikon van die betrokke taal. In hierdie artikel word daar slegs aandag gegee aan vaste uitdrukkings in algemene woordeboeke. Die term vaste uitdrukking word met 'n breë toepassing gebruik, naamlik om te verwys na idiome, spreekwoorde, gevleuelde woorde, ensovoorts, vergelyk in hierdie verband Gouws (1989). Die term algemene woordeboek moet breedweg geïnterpreteer word om na al daardie woordeboeke te verwys wat op 'n verteenwoordigende versameling items uit die algemene leksikon van 'n gegewe taal fokus.

Die bespreking in hierdie artikel is beperk tot gedrukte woordeboeke want hierdie woordeboeke word steeds gebruik, beplan en saamgestel en moet steeds 'n stewige metaleksikografiese basis hê. Talle aspekte wat ter sprake kom, is egter ook ter sake vir elektroniese woordeboeke. Vir meer inligting oor vaste uitdrukkings in elektroniese woordeboeke kan Bergenholtz, Bothma en Gouws (2011) geraadpleeg word.

In die ontwikkeling van die teoretiese leksikografie kan drie belangrike fases onderskei word wat elk 'n eie fokusgebied het, te wete 'n fokus op die taalkundige inhoud van woordeboeke (die sogenaamde Zgusta-fase), 'n fokus op die strukture van woordeboeke (die sogenaamde Wiegand-fase) en 'n fokus op die leksikografiese funksies van woordeboeke (die sogenaamde Bergenholtz en Tarp-fase), vergelyk in hierdie verband ook Gouws (2005) en Gouws en Prinsloo (2005). Ondanks die fokus op verskillende aspekte en ondanks die soms opponerende standpunte tydens hierdie fases is dit noodsaaklik om die wesenlike belang en tersaaklikheid van al drie hierdie fases vir die hedendaagse leksikografieteorie te erken. In die beplanning en samestelling van enige woordeboek moet die leksikograaf deeglik aandag gee aan besluite oor die inhoud, strukture en leksikografiese funksies van die beplande woordeboek.

Die gebruikersperspektief dwing elke leksikograaf wat beoog om 'n nuwe woordeboek saam te stel om die volgende belangrike vraag te beantwoord, naamlik "Wat wil ek hê, moet my gebruiker met die beplande woordeboek kan doen?" 'n Antwoord op hierdie vraag behoort te lei tot 'n vasstelling van die leksikografiese funksie(s) van die woordeboek. In ooreenstemming met die funksie(s) moet die data wat ingesluit moet word, gekies word en die vasstel- 
ling van die dataverspreidingstruktuur lei dan tot die vasstelling van ' $n$ verskeidenheid strukture met behulp waarvan die gekose data op die bes moontlike wyse aangebied, behandel en bereik kan word sodat die gebruiker die nodige inligting aan die data-aanduider kan onttrek.

Die gekose benadering tot inhoud, struktuur en funksies moet op 'n konsekwente en uitputtende manier toegepas word. Dit moet ook bepalend wees vir die keuse, aanbieding en behandeling van vaste uitdrukkings in algemene een- en tweetalige woordeboeke. Van hierdie aspekte met betrekking tot vaste uitdrukkings kom in hierdie artikel aan bod.

\section{Die keuse van vaste uitdrukkings}

Die keuse van vaste uitdrukkings wat in algemene woordeboeke opgeneem moet word, mag nie op 'n arbitrêre manier geskied nie. Dit moet met inagneming van die woordeboektipe, die funksies en die teikengebruikers van die beplande woordeboek gedoen word. In baie woordeboeke word die keuse van vaste uitdrukkings regstreeks beïnvloed deur die status wat leksikograwe aan hulle gee, naamlik as óf makro- óf mikrostrukturele inskrywings van die betrokke woordeboek. As makrostrukturele aanduiders word vaste uitdrukkings op grond daarvan gekies dat hulle volwaardige leksikale items van die betrokke taal is en dus kwalifiseer om as lemmata opgeneem te word, dit wil sê as volwaardige behandelingseenhede en dus as niegeadresseerde aanduiders. As mikrostrukturele items is hulle aanduiders wat gesien word as deel van die behandeling van ' $n$ ander lemma. Hulle is as aanduiders geadresseer aan die makrostruktuuraanduider en as behandelingseenhede is hulle hoogstens die teiken van prosedures van nielemmatiese adressering.

Woordeboeke vertoon dikwels ' $n$ inkonsekwentheid deur nie dieselfde teoreties gebaseerde kriteria vir die keuse van makro- en mikrostruktuurinskrywings te gebruik nie. Te dikwels gebruik leksikograwe bepaalde kriteria vir die keuse van makrostruktuurelemente maar laat die toepassing van daardie kriteria na in die besluite oor die keuse van mikrostruktuurelemente. Ter illustrasie hiervan: gebruiksfrekwensie speel ' $n$ belangrike rol in die keuse van lemmakandidate, maar hierdie kriterium speel 'n ondergeskikte rol in die keuse van byvoorbeeld die betekenisparafrases of die kollokasies wat in die behandeling van ' $n$ bepaalde lemma aangebied word. Waar vaste uitdrukkings as mikrostrukturele aanduiders aangebied word, is hulle deel van 'n artikel met 'n lemma as gidselement wat ooreenstem met 'n sleutelwoord uit die vaste uitdrukking. 'n Vaste uitdrukking soos Waar die hart van vol is, loop die mond van oor sal tipieserwys ingesluit word in die artikel van die lemmateken hart. Waar die artikelstruktuur voorsiening maak vir 'n soeksone vir vaste uitdrukkings probeer leksikograwe vaste uitdrukkings kry wat die woord wat deur die lemmateken voorgestel word as sleutelwoord bevat. Pogings om die soeksone van vaste uitdrukkings te beset, lei dikwels daartoe dat die leksikograaf nie die beginsel van gebruiksfrekwensie toepas in die keuse van mikrostruktuurin- 
skrywings nie. Waar een of meer vaste uitdrukkings met die verlangde sleutelwoord in die betrokke taal gevind word, word hulle in die gleuf vir vaste uitdrukkings opgeneem om die latente soeksone te bevolk en daardeur daartoe by te dra dat ' $n$ uitgebreide mikrostruktuur verwesenlik word. Volgens die voorwoord van die Tweetalige Skoolwoordeboek, 'n tweetalige skoolwoordeboek met Afrikaans en Engels as taalpaar, poog die woordeboek om daardie woordeskatitems op te neem wat dikwels deur die teikengebruikers van die woordeboek teëgekom word. In die artikel van die lemma hart is die vaste uitdrukking iemand ' $n$ hart onder die riem steek opgeneem. Dit is 'n verouderde Afrikaanse uitdrukking wat nie 'n kandidaat vir opname in hierdie woordeboek moes gewees het indien gebruiksfrekwensie werklik 'n kriterium was nie. As gebruiksfrekwensie ' $n$ bepalende rol speel in die keuse van leksikale items as lemmakandidate behoort dit ook ' $n$ rol te speel in die keuse van daardie leksikale items, soos vaste uitdrukkings, wat nie lemmastatus het nie maar eerder as mikrostrukturele aanduiders opgeneem word. Nogmaals behoort leksikografiese konsekwentheid 'n deurslaggewende rol te speel.

Die keuse van vaste uitdrukkings vir opname in woordeboeke moet volgens dieselfde dataverkrygingskriteria geskied as wat gebruik word vir die opname van ander leksikale items as behandelingseenhede in die betrokke woordeboek. In hierdie verband moet vaste uitdrukkings dus beoordeel word na aanleiding van hulle optrede as volwaardige leksikale items en nie as meerwoordige konstruksies wat die kombinatoriese vermoë illustreer van die leksikale item wat deur die lemmateken van die artikel waarin die vaste uitdrukking optree, verteenwoordig word nie.

\section{Die leksikografiese aanbieding van vaste uitdrukkings}

\subsection{Makro- of mikrostrukturele elemente}

Die insluiting van vaste uitdrukkings as mikrostrukturele aanduiders in ' $\mathrm{n}$ artikel waarvan die woord wat as gidselement optree, ooreenstem met ' $n$ woord in die vaste uitdrukking is sowel linguisties as leksikografies onaanvaarbaar, vergelyk Gouws (1989). Dit misken die status van vaste uitdrukkings as volwaardige leksikale items. Hierdie soort aanbieding bring mee dat die behandeling van die vaste uitdrukking met behulp van prosedures van nielemmatiese adressering gedoen word en dit lei daartoe dat die vaste uitdrukking ' $n$ minder prominente behandelingseenheid word.

Om hulle status as volwaardige leksikale items te weerspieël en om te verseker dat hulle ' $n$ behandeling kry wat gelykwaardig is aan dié van ander tipes leksikale items wat as lemmata opgeneem word, moet die plasing van vaste uitdrukkings as behandelingseenhede verhoog word en die vaste uitdrukkings wat gekies word om in 'n woordeboek opgeneem te word, moet as lemmakandidate oorweeg word.

Die lemmatisering van meerwoordige leksikale items is nie onproblema- 
ties nie. Dit geld ook vaste uitdrukkings. Om praktiese redes, byvoorbeeld die feit dat vaste uitdrukkings nie altyd 'n vaste eerste komponent het nie, is ' $n$ prosedure vasgelê om vaste uitdrukkings op so 'n manier in woordeboeke in te sluit dat hulle in of geheg aan die artikel van ' $n$ sleutelwoord uit die vaste uitdrukking verskyn. Hierdie metode kan redelik suksesvol uitgevoer word en hierdie tradisie sou ten dele behou kon word, maar dit verg 'n deeglike ondersoek na die posisie, aanbieding en status van 'n vaste uitdrukking tydens die uitvoering van hierdie metode. Dit is belangrik dat die vaste uitdrukking op so 'n manier aangebied moet word dat daar geen twyfel bestaan oor sy status as hetsy makro- hetsy mikrostrukturele element nie. In die besluitneming hieroor kan daar nogmaals aandag gegee word aan die insluiting van vaste uitdrukkings vanuit die perspektief van leksikografiese strukture.

\subsection{In 'n deelartikeltrajek}

Gouws (2010) pleit vir die insluiting van vaste uitdrukkings in 'n deelartikeltrajek wat geheg is aan maar nie ingesluit is nie in die artikel van 'n lemma wat 'n sleutelwoord uit die vaste uitdrukking verteenwoordig en waarvolgens die alfabetiese posisionering van die vaste uitdrukking kan geskied. Deur hulle insluiting in ' $\mathrm{n}$ afsonderlike deelartikeltrajek, selfs al bevat hierdie deelartikeltrajek slegs een artikel met ' $n$ vaste uitdrukking as sekondêre maar onmiddellike gidselement, word die status van vaste uitdrukkings as makrostruktuurelemente bevestig en benadruk. Sommige voorbeelde uit Gouws (2010) sal ook hier bespreek word.

Een van die onbevredigendste maniere waarvolgens vaste uitdrukkings in woordeboeke behandel kan word, is deur middel van 'n gegroepeerde mikrostrukturele kluster in 'n artikelgleuf wat vaste uitdrukkings en voorbeeldmateriaal in dieselfde kluster bevat sonder om hierdie verskillende tipes aanduiders hoegenaamd van mekaar te onderskei. Die hieropvolgende artikel uit Groot Woordeboek/Major Dictionary vertoon so 'n primitiewe mikrostruktuur sonder 'n mikro-argitektuur:

baan, (s) (bane), course, path, way, race (of moon), orbit (stars); trajectory (shell); court (tennis); rink (bowls, skating); floor (dancing); track (athl.); breadth, width, panel (cloth); permanent way, roadbed; lane (traffic); circuit (electr.); guide-way; gore (skirt); BREEK, pave the way; pioneer; op die BRING, bring on the tapis; op 'n GLADDE , on a slippery path; iem. v.d. KNIKKER, oust someone; op die LANGE , postponed indefinitely; shelved; ' $n \sim$ OPSKOP, kick up a row; die $\sim$ OPEN, open the dance; die $\sim R U I M$, clear the way; clear the floor; VAN die wees, be shelved; VRYE hê, have been given the right of way; v.d. $\sim$ WEES, have been put off (shelved); ...

Soms word vaste uitdrukkings so geplaas dat hulle as aanduiders elk in ' $\mathrm{n}$ eie semantiese subkommentaar van die artikel van 'n woordlemma optree. Vergelyk in hierdie verband die volgende uittreksels uit die artikel van die lemma- 
teken ear ${ }^{1}$ in die Collins Dictionary of the English Language:

$\operatorname{ear}^{1}(\ldots) n$. 1. the organ of hearing and balance ... 2. the outermost cartilaginous part of the ear ... 6. an object resembling the external ear ... 12. a flea in one's ear. Informal. a sharp rebuke. ... 26. wet behind the ears. Informal. youthful in manner or attitudes ...

$\mathrm{Al}$ is dit so dat die vaste uitdrukkings aangebied word as behandelingseenhede, impliseer hulle plasing hier steeds 'n mikrostrukturele en semantiese verhouding tot die lemma wat as gidselement van die spesifieke artikel optree. Toegang tot so ' $\mathrm{n}$ vaste uitdrukking is selfs vir die kundige woordeboekgebruiker nie onproblematies nie.

\subsection{Artikel-intern versus artikel-ekstern}

Vaste uitdrukkings word in verskillende posisies geplaas met betrekking tot die artikel van die lemma wat ooreenstem met die sleutelwoord uit die vaste uitdrukking. Sommige woordeboeke het 'n artikel-interne soeksone wat gereserveer is vir vaste uitdrukkings en duidelik gemerk is met behulp van 'n struktuurmerker. Vergelyk in hierdie verband byvoorbeeld die artikel van die lemmateken pineapple in The New Oxford Dictionary of English:

pineapple noun 1 a large juicy tropical fruit consisting of aromatic edible yellow flesh surrounded by a tough segmented skin and topped with a tuft of stiff leaves.

$2 \ldots$

3 Informal a hand grenade.

PHRASES the rough end of the pineapple Austral./NZ informal a situation in which someone receives unfair or harsh treatment.

ORIGIN late Middle English ...

Hierdie soeksone het 'n artikel-interne posisie en die vaste uitdrukkings word as mikrostrukturele inskrywings aangebied. Die gebruik van so 'n afsonderlike artikelgleuf verhoog toegang tot die vaste uitdrukkings en die struktuurmerker "PHRASES" skep 'n kitstoegangstruktuur. 'n Vergelykbare benadering kan gevind word in HAT, die Verklarende Handwoordeboek van die Afrikaanse Taal:

gat $^{1}$ (-e; gaatjie)

1 Opening in of holte deur of in 'n voorwerp: 'n Gat in hout boor. ' $n$ Gat in 'n sokkie stop. 'n Gat in jou tand hê. 'n Gat grawe om 'n boom te plant. Die Groot Gat by Kimberley. 'n Loer-, lug-, man-, sleutelgat. 2 Uitgeholde ruimte onder die grond: Molsgat. Erdvarke bly bedags in gate. $\nabla$ Jakkalse het gate en voëls het neste, maar die Seun van die mens het nie eers 'n rusplek vir sy kop nie (Matt. 8:20 NV). 3 Holte of duik in 'n landskap: Die dorp lê in 'n gat. 4 ... 8 Gebrek, leemte: Daar is groot gate in sy kennis. UITDR.: ' $n$ Gat in jou beursie hê, spandabel wees. ' $n$ Gat in die dag slaap, tot laat in die dag. Iets 
gate uit geniet (geselst.), dit baie geniet. Vir 'n ander 'n gat grawe en self daarin val, self in die moeilikheid beland wat jy vir 'n ander berei het. In die gate hou (veroud.), dophou, in die oog hou. Iemand ' $n$ gat in die kop praat, hom ompraat, omhaal - gewoonlik negatief gebruik. Gate ('n gat) uit speel, baie goed, lekker speel. ga'terig

Hierdie soeksone, aangedui deur die struktuurmerker "UITDR." ('n afkorting vir "uitdrukking"), bevat 'n kluster van vaste uitdrukkings. Op hierdie soeksone volg 'n artikelnis met slegs een artikel, naamlik 'n artikel met die sublemma gaterig as gidselement. Dit is nie sonder meer duidelik of hierdie kluster vaste uitdrukkings ' $n$ artikel-interne of 'n artikel-eksterne posisie het nie en daarom is dit nie sonder meer duidelik of die vaste uitdrukkings mikro- al dan makrostrukturele aanduiders is nie. Hulle word in 'n gleuf aangebied wat geskei is van die semantiese subkommentare van die betrokke artikel en hulle word as behandelingseenhede aangebied, al is dit slegs ' $\mathrm{n}$ beperkte behandeling wat aan elke vaste uitdrukking gegee word. Alhoewel die plasing van die kluster die indruk skep dat dit geïntegreerd is in die artikel van die lemmateken $g a t^{1}$ kan dit ook beskou word as 'n gegroepeerde nes wat die artikelnis wat vir onverklaarde enkelwoord komplekse lemmata voorsien is, voorafgaan. Hierdie nestingsprosedure verteenwoordig ' $n$ afwyking van die strak alfabetiese ordening wat die betrokke woordeboek kenmerk. Toegang tot die nes geskied via die vertikaal-geordende hooflemma van die voorafgaande artikel wat hier optree as artikel-eksterne primêre gidselement van elke vaste uitdrukking in die betrokke kluster. Toegang tot die indiwiduele vaste uitdrukkings geskied deur middel van 'n sekondêre alfabetiese prosedure, want die ordening van die vaste uitdrukkings in die kluster word gedoen volgens die alfabetiese waarde van 'n verdere woord uit die uitdrukking; nie die sleutelwoord wat as primêre gidselement optree nie. Deur hierdie vaste uitdrukkings as makrostruktuuraanduiders te beskou, kan die toegang tot elke vaste uitdrukking verhoog word deur die toepassing van 'n niegegroepeerde ordening, vergelyk in hierdie verband ook Bergenholtz, Tarp en Wiegand (1999) wat die deelartikeltrajek skei van die voorafgaande hoofartikel en wat ook 'n beter toepassing van die mikro-argitektuur daarstel. Vergelyk ook Gouws (2006):

gat $^{1}$ (-e; gaatjie)

1 Opening in of holte deur of in 'n voorwerp: ' $n$ Gat in hout boor. 'n Gat in 'n sokkie stop. 'n Gat in jou tand hê. 'n Gat grawe om 'n boom te plant. Die Groot Gat by Kimberley. 'n Loer-, lug-, man-, sleutelgat. 2 Uitgeholde ruimte onder die grond: Molsgat. Erdvarke bly bedags in gate. $\nabla$ Jakkalse het gate en voëls het neste, maar die Seun van die mens het nie eers ' $n$ rusplek vir sy kop nie (Matt. 8:20 NV). 3 Holte of duik in 'n landskap: Die dorp lê in 'n gat. 4 ... 8 Gebrek, leemte: Daar is groot gate in sy kennis.

UITDR.: 'n Gat in jou beursie hê, spandabel wees.

'n Gat in die dag slaap, tot laat in die dag.

Iets gate uit geniet (geselst.), dit baie geniet. 
Vir 'n ander 'n gat grawe en self daarin val, self in die moeilikheid beland wat jy vir 'n ander berei het.

In die gate hou (veroud.), dophou, in die oog hou.

Iemand 'n gat in die kop praat, hom ompraat, omhaal - gewoonlik negatief gebruik.

Gate ('n gat) uit speel, baie goed, lekker speel.

Al is hierdie vaste uitdrukkings geheg aan die artikel van die lemmateken gat $^{1}$ is hulle nie aan daardie lemma geadresseer nie. Trouens, hulle het geen adres nie, en dit is ' $n$ tipiese kenmerk van makrostruktuuraanduiders. Daarbenewens tree die vaste uitdrukkings ook nie op as mikrostruktuuraanduiders wat aangebied word as deel van die behandeling van die gegewe lemmateken nie. Hulle insluiting in die nabyheid van die spesifieke lemmateken is slegs om praktiese en toegangsredes met die lemmateken $g^{2} t^{1}$ waarvan die waarde met betrekking tot die kluster vaste uitdrukkings verminder word tot 'n verwyderde artikel-eksterne gidselement wat nodig is vir 'n deel van die eksterne toegangsproses tot die vaste uitdrukkings. Hierdie niegegroepeerde nes vaste uitdrukkings vorm 'n deelartikeltrajek, om meer presies te wees, 'n deelartikeltrajek van geneste artikels met 'n verwyderde deelartikeltrajek-eksterne primêre gidselement, en die nes word ingelei deur ' $n$ lemma-eksterne aanduidertipe- identifiserende struktuurmerker, naamlik die inskrywing "UITDR." Elke vaste uitdrukking in die kluster tree as gidselement van sy eie artikel op. Aangesien die lemma van die voorafgaande hoofartikel die eerste of primêre gidselement is op grond daarvan dat toegang tot elke vaste uitdrukking via daardie gidselement moet geskied, verteenwoordig die vaste uitdrukkings as lemmata sekondêre gidselemente. Daar kan dus geargumenteer word dat die vaste uitdrukkings as makrostruktuuraanduiders aangebied word maar wel as sublemmata omdat toegang tot hierdie lemmata afhanklik is van die voorafgaande hooflemma as primêre gidselement. Dit is belangrik om daarop te let dat die aanbieding as ' $n$ sublemma nie ' $n$ mindere makrostrukturele status of ' $n$ beperkter leksikografiese behandeling as ten opsigte van 'n hooflemma verstrek, impliseer nie.

Die manier waarop die vaste uitdrukkings in die hersiene uittreksel uit HAT aangebied is, gee erkenning aan hulle status as volwaardige leksikale items en aan hulle optrede as makrostrukturele behandelingseenhede. Hierdie status kwalifiseer vaste uitdrukkings vir 'n uitvoerige mikrostrukturele behandeling.

\section{Die behandeling van vaste uitdrukkings}

\subsection{Verskillende leksikografiese funksies}

Die behandeling van enige lemma in 'n woordeboek moet 'n poging wees om die leksikografiese funksies van daardie woordeboek te help bevredig. Daarom moet die datatipes en die aard en omvang van hulle aanbieding in enige woor- 
deboek bepaal word deur die leksikografiese funksies van daardie spesifieke woordeboek. In ' $n$ mono- of polifunksionele woordeboek moet daar ' $n$ parallel bestaan tussen die behandeling van vaste uitdrukkings en ander lemmata. Die verstekdataverspreidingsprogram mag anders wees as gevolg daarvan dat vaste uitdrukkings nie noodwendig al dieselfde aanduidertipes in hulle behandeling nodig het as wat in die behandeling van enkelwoordlemmata die geval is nie. 'n Aanduider wat die uitspraak aandui, is byvoorbeeld dikwels nie nodig in die behandeling van 'n vaste uitdrukking nie alhoewel dit as deel van die verpligte mikrostruktuur van die artikels van enkelwoordlemmata beskou mag word. Die behandeling van vaste uitdrukkings moet so volledig as moontlik wees met betrekking tot die datakategorieë wat nodig is vir 'n optimale ontsluiting van inligting oor die betrokke vaste uitdrukking en vir 'n bevrediging van die tersaaklike leksikografiese funksies.

In algemene woordeboeke is die behandeling van vaste uitdrukkings van veel beperkter en minderwaardiger gehalte as dié van enkelwoordlemmata. In eentalige verklarende woordeboeke kry ' $n$ mens dikwels ' $n$ kort betekenisparafrase en in tweetalige woordeboeke of ' $n$ vaste uitdrukking in die doeltaal wat as vertaalekwivalent aangebied word of ' $n$ betekenisparafrase in gevalle waar daar geen ekwivalente vaste uitdrukking in die doeltaal bestaan nie. Dit verteenwoordig dikwels die volle omvang van die behandeling.

Ander aanduidertipes is ook nodig om in die behoeftes van die tipiese woordeboekgebruiker te voorsien. Waar ' $n$ verklarende woordeboek ' $n$ kognitiewe funksie het, bevat die artikels dikwels ook 'n aanduider wat die etimologie gee van die woord wat deur die lemmateken verteenwoordig word. Dit is 'n datatipe wat ongelukkig nie dikwels genoeg gevind word in die behandeling van vaste uitdrukkings in algemene verklarende woordeboeke nie. Gebruikers raadpleeg dikwels 'n woordeboek vanweë 'n kognitiewe behoefte met betrekking tot vaste uitdrukkings en hulle is dikwels geïnteresseerd in die herkoms van die betrokke vaste uitdrukking. Nogmaals is leksikografiese konsekwentheid nodig. Wat vir die enkelwoordlemma geld, behoort ook waar nodig die vaste uitdrukking te geld. Gegee die behoefte aan etimologiese leiding by vaste uitdrukkings, soos blyk uit die navrae van woordeboekgebruikers aan uitgewers en leksikograwe, sou so ' $n$ aanduider van etimologie ' $n$ vaste inskrywing in die verstekbehandeling van vaste uitdrukkings kon word; al is dit nie deel van die verstekdata-oordrag in ander lemmatipes se artikels nie.

\subsection{Kommunikatiewe funksie}

Die kommunikatiewe funksie sluit drie subfunksies in, te wete teksresepsie, teksproduksie en vertaling, vergelyk Tarp (2008). Waar teksproduksie die geldende funksie is, het gebruikers redelik uitvoerige leiding nodig, byvoorbeeld met behulp van koteks- en konteksinskrywings. Die konteksinskrywings behoort ' $n$ wye verskeidenheid stilistiese etikette in te sluit en die kotekstuele inskrywings moet aanduiders bied wat tipiese gebruiksvoorbeelde van die aan- 
duider wat deur die lemma voorgestel word, weergee. Sowel een- as tweetalige woordeboeke laat te dikwels na om konteks- en koteksaanduiders te gee in die behandeling van vaste uitdrukkings. Dit is moontlik omdat vaste uitdrukkings veral as mikrostrukturele aanduiders optree en spesifiek as sou hulle kotekstuele leiding bied met betrekking tot die woord wat deur die eenwoordlemmateken verteenwoordig word.

As meerwoordige leksikale items bevat vaste uitdrukkings sekere verpligte elemente maar soms kan hulle ook opsionele elemente bevat, vergelyk Combrink (1989). In die geval van teksproduksie as funksie is dit belangrik dat woordeboekgebruikers daarvan bewus gemaak moet word of 'n gegewe vaste uitdrukking of sy vertaalekwivalent ook opsionele elemente bevat. Dit raak byvoorbeeld ook die optrede of afwesigheid van 'n ontkenningsvorm in ' $n$ vaste uitdrukking. Dit is naamlik belangrik om te weet of ' $n$ bepaalde vaste uitdrukking 'n negatiewe al dan 'n positiewe sinswaarde het, vergelyk Ponelis (1979). Vergelyk die volgende Afrikaanse vaste uitdrukkings:

1 die/'n bobbejaan agter die bult gaan haal

2 iets nie oor die hart kry nie

3 nie al jou kalwers in die hok hê nie

4 wie nie hoor nie moet voel.

Die eerste voorbeeld het ' $n$ positiewe sinswaarde maar die vaste uitdrukking kan ook genegativeer word en steeds as vaste uitdrukking gebruik word, byvoorbeeld nie die bobbejaan agter die bult gaan haal nie. Die tweede voorbeeld het ' $n$ negatiewe sinswaarde wat as sodanig gebruik word. Dit het normaalweg nie ' $n$ variant met 'n positiewe sinswaarde nie, behalwe wanneer die vaste uitdrukking in ' $n$ sin deur sekere bywoorde voorafgegaan word. Vergelyk in hierdie verband die volgende voorbeelde:

*? Ek kon dit oor my hart kry om die hondjie weg te gee.

Ek kon dit beswaarlik oor my hart kry om die hondjie weg te gee.

Voorbeeld 3 het ' $n$ negatiewe sinswaarde en word nooit positief gebruik nie. In normale Afrikaans kry ' $n$ mens dus nie ' $n$ sin soos die volgende nie:

*Jy kan staatmaak op wat hy sê want hy het al sy kalwers in die hok.

Voorbeeld 4 bevat sowel 'n negatiewe as 'n positiewe komponent maar ook hier is geen verandering van sinswaarde moontlik nie.

Hierdie tipe inligting is nuttig wanneer dit om teksproduksiehulp gaan. Gebruiksvoorbeelde waarin die vaste uitdrukkings optree, is waardevolle leksikografiese leiding. Die leksikograaf kan van die standpunt uitgaan dat dit die verstekwaarde is dat ' $n$ positiewe sinswaarde ook genegativeer kan word en andersom. Waar vaste uitdrukkings aan hierdie verstekwaarde voldoen, hoef dit nie eksplisiet gestel te word nie, maar daar sou 'n voorbeeld met sowel die positiewe as die negatiewe sinswaarde gegee kon word. Waar daar wel beper- 
kings ten opsigte van die sinswaarde bestaan en daarom met betrekking tot die aard van die sintaktiese patroon van 'n vaste uitdrukking, behoort dusdanige leiding in 'n woordeboek se behandeling aangebied te word. Voorbeeldsinne kan help, maar die leksikograaf sou ook 'n gebruiksnota, as artikel-interne binneteks, kon verstrek om die nodige leiding aan gebruikers te verskaf.

\subsection{Betekenisverhoudinge}

Gebruikers raadpleeg dikwels 'n woordeboek om inligting oor die betekenis van 'n gegewe lemma te onttrek. In 'n eentalige verklarende woordeboek vind die oordrag van betekenisleiding primêr deur middel van die aanduider van die betekenisparafrase plaas. Bykomende aanduiders wat ook 'n rol in hierdie verband kan speel, is onder meer aanduiders van sinonieme en antonieme ter verstrekking van bepaalde betekenisverhoudings waarin die leksikale item wat deur die lemma verteenwoordig word, kan optree. In die leksikale semantiek is dit reeds duidelik gestel dat absolute sinonieme heel skaars is. In die meeste gevalle waar daar sprake is van sinonimie gaan dit om verhoudings van gedeeltelike sinonimie. Gedeeltelike sinonieme kan mekaar in sommige gebruiksomgewings vervang maar verskil van mekaar in terme van hulle onderskeie polisemiese paradigmas, hulle styl, register en ook gebruiksoptrede. Sinonimie is nie 'n verhouding wat slegs tussen woorde geld nie. Dit geld tussen leksikale items en daarom kan vaste uitdrukkings ook deel hê aan sinonimiese verhoudings. Sinonimie geld ook oor die grense van verskillende tipes leksikale items heen. Vaste uitdrukkings kan daarom sowel woorde as ander meerwoordige leksikale items as sinonieme hê.

In die artikels van enkelwoordlemmata word sinonieme dikwels aangedui en wel met die doel om as teksproduksiehulp die gebruiker die moontlikheid tot 'n meer gevarieerde taalgebruik te bied. Waar vaste uitdrukkings in 'n woordeboek met 'n teksproduksiefunksie ingesluit word, behoort die gebruiker soortgelyke hulp van die woordeboek te kan verwag as wat in die artikels van enkelwoordlemmata gevind word.

Gedeeltelike en absolute sinonieme, sowel woorde as ander vaste uitdrukkings, behoort as deel van die behandeling van die vaste uitdrukking gegee te word, maar verskille in styl, register en gebruik asook beperkings in die betekenisoorvleueling moet duidelik aangetoon word.

Afrikaans het 'n verskeidenheid vaste uitdrukkings met die betekenis "om dood te gaan". Hierdie uitdrukkings strek vanaf die formele die tydelike met die ewige verwissel tot die hoogs informele om die lepel in die dak te steek. In die behandeling van hierdie vaste uitdrukkings moet daar onder meer 'n betekenisparafrase verstrek word maar dan ook een of meer sinonimiese vaste uitdrukkings. Elke vaste uitdrukking met hierdie betekenis hoef nie telkens in die behandeling van elk gelys te word nie. Een vaste uitdrukking kan op grond van gebruiksfrekwensie gekies word om 'n volledige lysting van die sinonimiese vaste uitdrukkings te bevat. In die artikels van die ander vaste uitdruk- 
kings kan daar dan telkens 'n kruisverwysing na hierdie lemma gegee word. Meer data as die blote kruisverwysingsmerker is egter nodig om gebruikers bewus te maak van die tersaaklike styl- en registerbeperkings. Hier kan die benutting van ' $n$ stelsel van leksikografiese etikettering ' $n$ belangrike rol speel.

Waar ' $n$ woordeboek teksproduksie as funksie het, kan dit ook belangrik wees dat gebruikers ingelig moet word oor woorde en vaste uitdrukkings, ook gedeeltelike sinonieme, waarmee ' $n$ bepaalde vorm maklik verwar kan word. Die behandeling wat in 'n artikel gebied word, behoort in sulke gevalle nie tot 'n geïsoleerde aanduiding van sinonieme beperk te wees nie. Afrikaans het die vaste uitdrukkings nie 'n vinger verroer nie en nie ' $n$ voet versit nie. Hierdie twee vaste uitdrukkings is gedeeltelike sinonieme met die betekenis "om niks te doen nie". Albei vaste uitdrukkings behoort op hulle onderskeie alfabetiese plekke in die woordeboek opgeneem te word. 'n Aanduider van die betekenisparafrase van hierdie vaste uitdrukkings soos "om niks te doen nie" wat heel dikwels in Afrikaanse woordeboeke gevind word, is nie voldoende om suksesvolle prosedures van teksproduksie te verseker nie. Voorbeeldmateriaal wat as koteksaanduiders verstrek word, is byvoorbeeld nodig maar sulke aanduiders sal nie noodwendig voldoende wees om gebruikers bewus te maak van die geldende gebruiksbeperkings nie. Bykomende leksikografiese data is nodig. Dit kan byvoorbeeld gedoen word deur 'n aanduider, geadresseer aan die gedeeltelike sinoniem, wat die gebruiksbeperking van die gegewe sinoniem met betrekking tot die vaste uitdrukking waaraan die gedeeltelike sinoniem geadresseer is, verstrek. Alhoewel albei die genoemde vaste uitdrukkings die betekenis "om niks te doen nie" het, is die aard van die "niks" nie dieselfde nie. In nie ' $n$ vinger verroer nie verwys die "niks" tipieserwys na 'n vorm van hulp of bystand, byvoorbeeld:

Ek moes die werk alleen doen want hy het nie ' $n$ vinger verroer om my te help nie.

In nie ' $n$ voet versit nie verwys die "niks" eerder na fisiese beweging, byvoorbeeld:

Sy was die hele tyd in haar kamer en het nooit 'n voet versit nie.

Die insluiting van sinonieme as aanduiders in die behandeling van vaste uitdrukkings verhoog die gehalte van die mikrostrukturele dekking en dit lei tot ' $n$ beter balans tussen die leksikografiese behandeling van vaste uitdrukkings en enkelwoordlemmata en dra ook by tot ' $n$ omvattender uitvoering van die leksikografiese funksies wat vir 'n bepaalde woordeboek vasgestel is. Aanduiders van sinonieme behoort ook in die behandeling van vaste uitdrukkings in tweetalige woordeboeke verstrek te word.

\subsection{Kultuurverskille}

Waar die taalgemeenskappe van die taalpaar van 'n tweetalige woordeboek tot 
verskillende kulture behoort, kan dit dikwels tot probleme lei in die behandeling van vaste uitdrukkings. Vir 'n gegewe betekenis kan 'n spesifieke taal ' $n$ vaste uitdrukking hê wat 'n blote vertaling is van 'n vaste uitdrukking wat ook in verskeie ander tale, insluitende die tweede taal van die betrokke woordeboek, gebruik word. Die spesifieke taal kan egter ook 'n kultuurspesifieke vaste uitdrukking hê met dieselfde betekenis as die vaste uitdrukking wat 'n vertaling uit ander tale is. In 'n veeltalige land soos Suid-Afrika kan dit dikwels die geval wees. Tweetalige woordeboeke behoort sowel die algemene as die kultuurspesifieke uitdrukking te bevat met 'n duidelike aanduiding dat die een ' $n$ kultuurspesifieke beperking het en dus nie in die tweede taal vertaal moet word nie. Vir die bekende Engelse vaste uitdrukking the tip of the iceberg is daar 'n Afrikaanse ekwivalent, naamlik die vertaling die puntjie van die ysberg. Hierdie ekwivalent behoort in ' $n$ tweetalige woordeboek met Engels en Afrikaans as taalpaar verstrek te word in die behandeling van die gegewe Engelse vaste uitdrukking. Ysberge is nie so bekend in Suid-Afrika nie; seekoeie wel. Die betekenis van die puntjie van die ysberg kan in Afrikaans ook geleksikaliseer word as die vaste uitdrukking die oortjies van die seekoei. In die behandeling van the tip of the iceberg moet hierdie vaste uitdrukking ook verstrek word, maar dit moet geëtiketteer word as 'n kultuurspesifieke leksikale item.

Nie net die kommunikatiewe funksie nie maar ook die kognitiewe funksie van tweetalige woordeboeke vereis ' $n$ uitvoeriger behandeling van vaste uitdrukkings. In die behandeling van kultuurspesifieke leksikale items, in hulle aanbieding as hetsy enkelwoord- hetsy meerwoordige lemmata, is bykomende inskrywings van groot waarde om die kulturele inhoud van sulke items aan te toon. Die gebruik van artikel-interne ingevoegde binnetekste of van tekskassies kan help met die vereenduidiging van kultuurgebonde vaste uitdrukkings in die brontaal. Xhosa het die vaste uitdrukking yaghawuk'imbeleko wat letterlik vertaal kan word as "die riem het gebreek", met die betekenis dat daar 'n versteuring in of verbreking van 'n verhouding was of dat daar 'n skeiding was tussen mense of dinge wat met mekaar vereenselwig word. Afrikaans het geen vaste uitdrukking as ekwivalent vir hierdie Xhosa uitdrukking nie en die behandeling hiervan in ' $n$ tweetalige woordeboek sal deur middel van ' $n$ betekenisparafrase wat as surrogaatekwivalentaanduider aangebied word, moet wees. Vir teksresepsiedoeleindes behoort dit voldoende te wees. Waar die woordeboek egter (ook) 'n kognitiewe funksie het, sal 'n blote surrogaatekwivalent nie verseker dat die werklike doel van die woordeboek bereik word nie. In die tradisionele Xhosa-gemeenskap dra vrouens dikwels hulle babas op die rug en die baba word aan die vrou of aan haar rok vasgebind. Wanneer hierdie riem waarmee die baba aan haar vasgebind is per ongeluk breek, word ' $n$ baie intieme verhouding versteur of gebreek. Om die omvang van die emosionele waarde te begryp wat deur die betrokke Xhosa- vaste uitdrukking geleksikaliseer word, is meer leiding nodig as dit wat deur 'n surrogaatekwivalent wat maar ' $n$ beperkte betekenisparafrase gee, gebied word. ' $n$ Tekskassie of ' $n$ artikel-interne ingevoegde binneteks kan gebruik word om data oor die kulturele 
waarde van hierdie vaste uitdrukking oor te dra. Indien die betrokke woordeboek 'n raamstruktuur vertoon, sou 'n alternatiewe moontlikheid wees om in die artikel van die vaste uitdrukking, naas die surrogaatekwivalent, 'n kruisverwysing te gee wat die gebruiker lei na 'n buiteteks in die agtertekste-afdeling van die woordeboek waar 'n uitvoeriger bespreking van alle kultuurgebonde leksikale items van albei die behandelde tale verstrek word. So 'n behandeling in 'n buiteteks vestig ' $n$ transtekstuele benadering tot leksikografiese funksies, vergelyk Gouws en Steyn (2005), en bevestig 'n uitputtende toepassing van die benadering tot leksikografiese funksies wat vir die betrokke woordeboek vasgestel is. Deur sowel vaste uitdrukkings as ander lemmata van die sentrale teks in 'n enkele tematies-gemotiveerde buiteteks te betrek, bewys nogmaals die status wat in die woordeboek aan vaste uitdrukkings verleen word.

'n Tradisionele aanbieding van vaste uitdrukkings as mikrostrukturele aanduiders lei normaalweg nie tot 'n uitvoerige behandeling nie. Deur vaste uitdrukkings as makrostrukturele aanduiders te erken en hulle artikels as kandidate vir 'n gevarieerde artikel- en mikrostruktuur te beskou, word die moontlikheid geskep vir 'n verteenwoordigende en bevredigende leksikografiese behandeling en dit bring mee dat die woordeboek 'n geldige weerspieëling van 'n groter deel van die leksikon bied wat in sy teikengebied val.

\section{Ter afsluiting}

As makrostruktuuraanduiders en volwaardige behandelingseenhede verg vaste uitdrukkings ' $n$ nuwe oordeel oor hulle artikelstruktuur asook oor die mikrostrukturele program en dataverspreidingstruktuur van die betrokke woordeboek. Die inhoud, struktuur en funksies wat vir artikels met enkelwoordlemmata beplan word en as die verstekaanbieding van die woordeboek dien, moet sistematies en volledig toegepas word en ook op subwoordelike en meerwoordige lemmata, insluitend vaste uitdrukkings, gerig word. Leksikograwe moet besef dat vaste uitdrukkings volwaardige behandelingseenhede is en nie as deel van die behandeling van ' $n$ woordlemma aangebied moet word nie.

Die keuse, aanbieding en behandeling van vaste uitdrukkings stel leksikograwe voor ' $n$ wye reeks uitdagings. Die kwessies wat in hierdie artikel bespreek is, is slegs die oortjies van die idiomatiese seekoei.

\section{Acknowledgement}

This work is based on the research supported in part by the National Research Foundation of South Africa (Grant specific unique reference number (VID) 85434).

The Grantholder acknowledges that opinions, findings and conclusions or recommendations expressed in any publication generated by the NRF sup- 
ported research are those of the author, and that the NRF accepts no liability whatsoever in this regard.

\section{Bibliografie}

Bergenholtz, H., T.J.D. Bothma en R.H. Gouws. 2011. A Model for Integrated Dictionaries of Fixed Expressions. Kozen, I. en K. Kosen (Reds.). 2011. Electronic Lexicography in the 21st Century: New Applications for New Users: 34-42. Ljubljana: Trojina, Institute for Applied Slovene Studies.

Bergenholtz, H., S. Tarp en H.E. Wiegand. 1999. Datendistributionsstrukturen, Makro- und Mikrostrukturen in neueren Fachwörterbüchern. Hoffman, L. et al. (Reds.). 1999. Fachsprachen. Ein internationales Handbuch zur Fachsprachenforschung und Terminologiewissenschaft/Languages for Special Purposes. An International Handbook of Special-Language and Terminology Research, Bd./ Vol. 2: 1762-1832. Berlyn: Walter de Gruyter.

Combrink, J.G.H. 1989. Wesenlike elemente, ekstras en vulsels in die aangawe van idiome in tweetalige woordeboeke. Botha, T.J.R. (Red.). 1989. Leksikografie en leksikologie: 55-77. Menlopark: Serva Uitgewers.

Eksteen, L.C. et al. (Reds.). 199714. Groot Woordeboek Afrikaans-Engels/Engels-Afrikaans / Major Dictionary Afrikaans-English/English-Afrikaans. Kaapstad: Pharos.

Gouws, L. 2006. Die behandeling van vaste uitdrukkings in tweetalige woordeboeke: ' $n$ Hulp vir vertalers. Ongepubliseerde M.Phil.-skripsie. Stellenbosch: Universiteit van Stellenbosch.

Gouws, R.H. 1989. Leksikografie. Pretoria/Kaapstad: Academica.

Gouws, R.H. 2005. Meilensteine auf dem historischen Weg der Metalexikographie. Lexicographica 21: 158-178.

Gouws, R.H. 2010. Fixed Word Combinations as Second Level Treatment Units in Dictionaries. Ďurčo, P. (Red.). 2010. Feste Wortverbindungen und Lexikographie: 51-63. Berlyn: Walter de Gruyter.

Gouws, R.H. en D.J. Prinsloo. 2005. Principles and Practice of South African Lexicography. Stellenbosch: SUN PReSS.

Gouws, R.H. en M. Steyn. 2005. Integrated Outer Texts: A Transtextual Approach to Lexicographic Functions. Barz, I., H. Bergenholtz en J. Korhonen (Reds.). 2005. Schreiben, Verstehen, Übersetzen und Lernen: $\mathrm{Zu}$ ein- und zweisprachigen Wörterbüchern mit Deutsch: 127-136. Frankfurt a.M./Bern/New York/Parys: Peter Lang.

Hanks, P. (Red.). 19852. Collins Dictionary of the English Language. London/Glasgow: Collins.

Odendal, F.F. en R.H. Gouws (Reds.). 20004. Verklarende Handwoordeboek van die Afrikaanse Taal. Midrand: Perskor.

Pearsall, J. (Ed.). 1998. The New Oxford Dictionary of English. Oxford: Clarendon Press.

Ponelis, F.A. 1979. Afrikaanse sintaksis. Pretoria: Van Schaik.

Tarp, Sven. 2008. Lexicography in the Borderland between Knowledge and Non-knowledge. General Lexicographical Theory with Particular Focus on Learner's Lexicography. Tübingen: Max Niemeyer.

Tweetalige Skoolwoordeboek/Bilingual School Dictionary. 2012. Kaapstad: Pharos Woordeboeke. 